\title{
The Implementation of E-Procurement in Indonesia: Benefits, Risks, and Problems
}

\author{
Nurus Sa'adah \\ UIN Sunan Kalijaga, Yogyakarta, Indonesia \\ nurus.saadab@uin-suka.ac.id
}

\begin{abstract}
E-procurement was a new model of muamalah applied in the procurement in several countries in the world. Indonesia was implemented from 2010, but the implementation was not maximal. Proven there were still doubts to use this modern muamalah model. So, this research aimed to find information on how e-procurement was implemented in Indonesia. Data were obtained from a questionnaire containing a list of structured and open questions provided to government agency procurement officers, provider staff, and secondary data from e-procurement research in several local governments in Indonesia. The results showed that the implementation of e-procurement reduced fraud. Benefit (maslahab) e-procurement was proven to be more than the risk (mafsadat). There were still doubts about sharia in the implementation of procurement due to a lack of information. The implementation of e-procurement still needs the attention to strengthening the quality of procurement officials, regulations, supervision, and internet support so that e-procurement success.
\end{abstract}

Keywords: benefit, e-procurement, risks

Permalink/DOI: https://doi.org/10.18326/infsl3.v14i2. 283-304 


\section{Introduction}

Ideal financial reporting is accountable and transparent, but in reality, in financial reporting, it is often problematic especially related to the procurement of goods and services. From year to year, cases of procurement of goods and services in various agencies, especially government agencies, are increasing. This alarming condition can be seen in the data uploaded by ACCH (Anti-Corruption Clearing House) as of December 31, 2018, in figure 1 below.

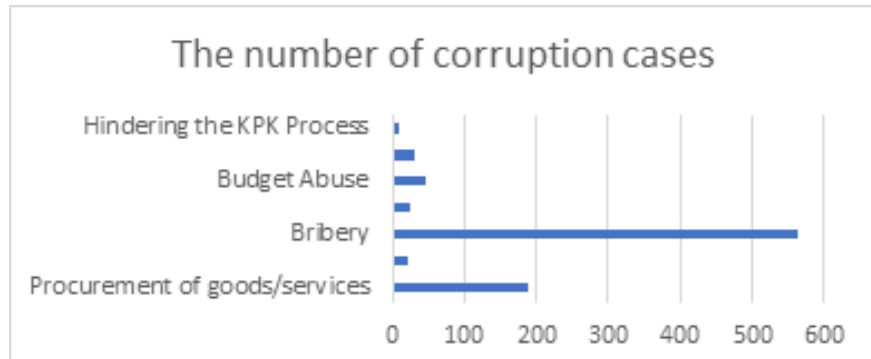

\section{Figure 1. Data on Corruption Cases in Indonesia}

Source: ACCH Data year 2004-2018

Corruption is a major problem in several countries including Indonesia (Nurmandi, 2013; Ariani \& Jati, 2016). From figure 1 it appears unequivocally, that corruption in Indonesia can be mapped in 7 groups of cases. Procurement of goods/services, although not the highest corruption case, the procurement of goods/services ranks second after bribery corruption (Nurlukman, 2017). Related to the procurement of goods/services, e-procurement becomes one of the solutions to bring down corruption cases (Achterstraat, 2011; Nurmandi, 2013; Neupane et al., 2012; Nurmandi \& Kim, 2015) because in traditional procurement consists of several phases, each of which has the opportunity to risk corruption (Neupane et al., 2012).

To reduce the problem in Indonesia, LKPP (Government Procurement Policy Institute) as a Non-Ministerial Government Agency (LPNK) bringing up an innovative program called e-procurement. This is contained in the determination of Perpres 54 the Year 2010 which contains the procurement on an e-procurement (Wulandari et al., 2014).

The purpose of e-procurement according to Ariani \& Jati (2016) is 
to increase transparency and accountability, to improve market access and healthy business competition, to improve the efficiency of the procurement process, to supports monitoring and auditing process, and to meet real-time information access needs.

However, after e-procurement was enacted, it turned out to raise many unresolved questions so many procurement officials were still hesitant because they did not have enough information (Fernandes \& Vieira, 2015). Moreover, because the position of the procurement officials of this goods procurement is a risky, wrong a little will be fatal, then they prefer to be very careful. Some of the considerations that make doubt are that buying and selling transactions generally present goods that are traded, while e-procurement is only by electronics (Hediana \& Aly, 2015).

Meanwhile, this e-procurement inevitably has to be run because it has been in line with the challenges of the technological era (Fernandes \& Vieira, 2015; Shukla et al., 2016) with a variety of effective and efficient service facilities especially in the era of industrial revolution 4.0 and in the COVID-19 pandemic where it must maintain physical distance between people and use strict health protocols. Therefore, this e-procurement is the right choice.

In some countries, this e-procurement has proven to have many advantages among suppliers there will be healthy competition (Hanna, 2010), reducing the interference of other parties in the auction process (Khanapuri, 2011), avoiding project/purchase irregularities (Achterstraat, 2011), more transparent and accountable (Innocent \& Kalaskar, 2016; Neupane et al., 2012), can be applied in various business lines of both companies, small and medium enterprises, and governments (Ariani \& jati, 2016), and impacts on the lack of trading monopolies, information asymmetry, trust, transparency, and accountability (Neupane, 2014). Some of these studies looked at e-procurement only from its advantages, and some of it included vaidya et al research. (2006) only looking for data from buyers only. This research will improve by focusing not only on the benefits but also looking at the risks of e-procurement. Also, this research also involves procurement staff and goods/service providers to obtain more accurate, valid, and comprehensive data.

Based on these considerations, the formulation of the problem in 
this study is How is the implementation of e-procurement in Indonesia? What are the benefits and risks of e-procurement when applied to agencies in Indonesia? What problems occur when implementing e-procurement?

In line with the era of the industrial revolution 4.0, all lifelines inevitably have to walk adaptively following the challenges of the times. The implementation of e-procurement is the implementation of the initial process of offering goods/services until the entire transaction process ends (Vaidya, Sajeev, \& Callender, 2006). Almost all manual activities turn into automated and practical digital to meet fast and precise service. Similarly, the procurement of goods and services carried out in agencies, especially government agencies of the Republic of Indonesia leads to digital-based procurement, called e-procurement (electronic-based procurement) in which there is e-purchasing with e-catalog media.

An electronic catalog is an electronic information system that contains a list, brand, type, technical specification, price, and amount of available goods/services specific to the various provider. This electronic catalog is the transformation of procurement from the old paradigm to a new paradigm in the procurement of goods and services or e-purchasing (Muhaimin, 2019). The term e-catalog in the conventional sense was first popular as a stock data book in the library that can only be accessed in the Library Building, but due to the sophistication of technology, e-catalogs are currently a popular means of explaining the stock of all products offered to the public at large without having to come to the provider (Linda, 2016). Some of the paradigm differences are listed in table 1 below.

Table 1. The Procurement Transformation According to

Presidential Decree 80/2003 and Presidential Regulation 54/2010 jo Presidential Regulation 4/2015

\begin{tabular}{llcc}
\hline No & \multicolumn{1}{c}{ Aspects } & Old Paradigm & New paradigm \\
\hline 1. & $\begin{array}{l}\text { Number of } \\
\text { Procurement } \\
\text { Packages } \\
\text { (Contracts) }\end{array}$ & Many (individual) & Bit (group/shared)
\end{tabular}




\begin{tabular}{|c|c|c|c|}
\hline No & Aspects & Old Paradigm & New paradigm \\
\hline 2. & Buy Price & Above market price & Market driven \\
\hline 3. & Implementation & $\begin{array}{l}\text { Transactional/ } \\
\text { Circular }\end{array}$ & Strategic \\
\hline 4. & Procces & Long/Complicated & Simple \\
\hline 5. & Contracts & Long-term & Long-term \\
\hline 6. & $\begin{array}{l}\text { Administration } \\
\text { Fee }\end{array}$ & High & Low \\
\hline 7. & Method & Manual & $\begin{array}{l}\text { Using electronic aids } \\
\text { (e-procurement) }\end{array}$ \\
\hline 8. & Scope & $\begin{array}{l}\text { Procurement } \\
\text { \& Contracts } \\
\text { management }\end{array}$ & $\begin{array}{l}\text { Procure to pay } \\
\text { (procurement-contract } \\
\text { management-payment) }\end{array}$ \\
\hline
\end{tabular}

Source: Muhaemin, E.A. (2019). Policies in E-Purchasing and E-Catalog. Directorate of Catalog-LKPP System Development.

The implementation of this e-purchasing refers to Presidential Regulation No. 4 of 2015 article 110 described as follows. First, in the framework of e-purchasing, the electronic catalog system (e-catalog) at least contains technical information and goods/service prices. Second, the electronic catalog system as referred to in paragraph (1) shall be organized by LKPP. Goods/services listed in the electronic catalog are determined by the Head of LKPP. Third, deleted. Fourth, $\mathrm{K} / \mathrm{L} / \mathrm{D} / \mathrm{I}$ is obliged to e-purchasing goods/services that have been loaded in the electronic catalog system according to the needs of K/L/D/I. Fifth, E-purchasing is carried out by procurement officials/ PPK or schedules determined by the Head of The Institution. Sixth, further provisions regarding e-Purchasing are set by LKPP.

Based on the description of the e-purchasing policy, reinforced by the president's decision as described above, it is appropriate that all agencies, especially government agencies implement this e-procurement policy in the procurement process of goods/ services. But in facts there are still many agencies that have not implemented optimally, Nurmandi (2013) explained only 62\% of districts in Indonesia that have implemented e-procurement. Therefore, the formulation of the problem in this study is what are 
the advantages and risks of procurement of goods/services through e-procurement carried out by government agencies. This research is preliminary research for the development of in-depth research on the transformation of e-procurement in Indonesia.

E-procurement is a process of procurement of goods and services using information and communication technologies (ICT). Discussing e-procurement, there are 4 related things, namely training and development for people involved in e-procurement activities, procurement security, the readiness of procurement actors to use ICT, and the impact of technology-based procurement (Innocent \& Kalaskar, 2016).

Research on e-procurement itself in various countries has been considerable, such as India (Khanapuri, 2011), Australia (Achterstraat, 2011; Innocent \& Kalaskar, 2016), Nepal (Neupane, 2014), Malaysia (Nawi et al., 2016), and fifty countries that have used e-procurement such as Bahrain, Norway, Italy, Singapore, Turkey, India, Malaysia, Peru, Pakistan, and others (Neupane et al., 2012). However, as explained by Nurmandi (2013), e-procurement research in Indonesia is still very rare. Some of what has been done is e-procurement research related to electronic catalogs on the scope of procurement dan availability of drugs in hospitals (Ningsih et al., 2015; Saputra et al., 2019), e-catalog at The Regional Archives and Documentation Library Agency (BPAD) Lampung (Linda, 2016), local and national government institutions (Nurmandi, 2013), and comparison of e-procurement in Yogyakarta, Tangerang, and Kutaikartanegara (Nurmandi \& Kim, 2015).

Referring to Innocent \& Kalaskar (2016), Benefits of adoption of e-procurement are described. Cost-effective: the use of e-procurement can lower costs by up to $65 \%$ so this can increase sales volume because it will result in better prices from suppliers and more fun when negotiating with suppliers. Process efficiency: If the organization prepares tools to spend analysis, transaction analysis, market analysis, and others related to strategic activities, the use of these tools will improve the e-procurement process better. Better information flow between a firm and suppliers. The flow of information between suppliers and user companies 
can be better: because the computer system and internet network will facilitate suppliers to share information about various goods/ services directly. Reduced maverick spending: e-procurement allows organizations to reduce maverick spending by utilizing the internet by reducing insecurity and uncertainty at purchasing the necessary resources from suppliers who have no formal relationship with the organization. Streamlined Process: e-procurement allows organizations to streamline the procurement process because internet media allows companies to make direct contact with their suppliers thus eliminating intermediaries, thereby generating significant revenue for both parties. Better Inventory Level: the e-procurement process can check for request placement or order errors such as double data and so on to control the stock precisely and quickly. Better services to customers: suppliers and customers alike can connect with each other's organizations so that the service becomes better. Improved speed of services to customers: with the internet, information exchange between providers and customers can be faster.

The risks of e-procurement according to Innocent \& Kalaskar (2016) are as follows. Internal business risks: for the e-procurement system to work better, not only are system requirements required but must also be integrated with existing infrastructure information. External business risks: as well as internal integrase, the company also needs to integrate with external customers such as suppliers, who also need investment to develop the system. because there will be a lot of information exchange, there is always the risk of information leakage. Technology risks: Procurement systems must have clear and open standards such as coding, technical, and process specifications that can facilitate electronic procurement technology between organizations or may limit and slow down the electronic procurement process E-procurement process risks: when using an e-procurement system, organizations should also have internetconnected security guarantees.

\section{Methods}

This research is a qualitative study using collection from primary and secondary sources. The primary source is interviews of 11 staff who handle the procurement of goods/services from 4 government 
agencies and representatives from several e-catalog sales staff from July 1 to July 20, 2019, in Yogyakarta. The instrument used is a questionnaire containing a list of open questions equipped with interviews as a compliment. Questionnaires are given separately to procurement officers of government agencies and sellers or providers of goods/services. Metode data analysis from this questionnaire is done using interpretive analysis. The analysis technique is to analyze the experience of procurement officials from 4 government agencies related to the benefits and risks of implementing this e-procurement.

Also, secondary studies were conducted on some of the results of previous research on e-procurement in several regions in Indonesia. To ensure the validity of all data used triangulation technique (Sugiyono, 2010). Triangulation is used to check the correctness of data both from structured interviews in polls and during interviews and documentation from previous researches to reduce bias.

\section{Results and Discussion}

The implementation of e-procurement in Indonesia has begun to expand even though it has not been running to the maximum. Some local governments already carry out e-procurement for procurement in their agencies because they follow the procurement rules set by the Government Procurement Policy Institute (LKPP) of the Republic of Indonesia.

This e-procurement has also been shown to be very helpful in several procurements of goods/services in various regions in Indonesia, including in the procurement project of the construction of the Wedding Hall Building and Manasik Haji KUA Cipari Cilacap Regency which uses the concept of zimmah-ijarah. Ministry of Religious Affairs as mu'jir and provider as musta'jir can carry out procurement transactions smoothly and maslahah (no cheating) (Apriyanto, 2019). Similarly, the implementation of government agencies in Malang shows that e-procurement can reduce irregularities in the procurement of construction work (Wulandari et al., 2014). The implementation of e-procurement in Yogyakarta was carried out by the committee at LPSE in each SKPD, at the 
beginning of its implementation is still not maximal so it is considered unaccountable, there is still collusion between procurement officials and provider partners. But fortunately, there is still strong scrutiny from various parties (Udoyono, 2012).

E-procurement is also proven to improve transparency and accountability in the procurement of goods/services in local governments in Lombok island so that fraud loopholes can be reduced (Artantri et al., 2016). In previous research on procurement of goods/services in Bogor city government shows that the more pressure that procurement officials receive, the less likely procurement fraud, while the more opportunities, rationalization, and capabilities in government procurement, the more likely the government procurement fraud in Bogor city government (Purwanto et al., 2017). Such concerns occurred in procurement in the Bogor city government that allowed fraud to occur also in some areas throughout Indonesia. Therefore, Pekanbaru city government prepares reliable human resources that can work accountably and a big budget to support the quality of the internet network so that there are no obstacles in the implementation of e-procurement (Swadesi \& Sadad, 2017).

In addition to secondary data derived from the results of e-procurement research in Indonesia, this research also collects primary data from procurement officials and providers of goods and services to see the benefits and risks, as well as problems that occur around the implementation of e-procurement. Data collection results are analyzed separately between data derived from users or procurement staff and data from goods/service providers. Both are described in the following details.

Based on the data collection of procurement staff can be explained as follows. Before there was e-procurement, a budget for goods/services is not suitable for example below the market price because the price is very volatile even though the budget was made in the previous year. E-procurement makes it faster to detect market prices. E-procurement accelerates the realization of the budget. In the past before e-procurement, the realization of the budget crowded at the end of the year and not according to the budgeting 
schedule even if the goods sought are empty of stock, it will reverse the realization of its budget.

Before e-procurement, letter of accountability completeness documents are complicated and take a long time to complete. The length of time this can be from internal can be because external e.g. SPJ (letter of accountability) files are not immediately returned by the partner. Temporary Estimated Price (HPS) has not accommodated postage and installation costs and not all providers of goods/services are willing to provide HPS friendly when prospective buyers have to survey prices to determine HPS. With e-procurement, just check in the application.

Risks arise sometimes from the provider's server, sometimes also from the buyer so that it responds sometimes long. More so by the end of the year, perhaps because soaring demand caused server errors so there was not enough time for the realization of that year's budget due to many rejections from providers. Also, the provider's HR is limited, making it difficult to negotiate several times.

In addition to the above, several conditions distinguish between conventional procurement and e-procurement according to the procurement staff, namely as follows. Many agencies are confused to choose because many providers offer goods/services. As soon as you browse, a lot comes up. This is a bit different from conventional procurement that only meets the partners we are aiming for. Conventionsneed to structure HPS, selecting competent providers more at risk related to supervision by the relevant parties. As for e-catalog, it is easier, more transparent, safer, despite the high postage. E-procurement offers by request e-catalog usually do not use the offer letter or it can be said that the offer letter is given by request that is when the agency asks for a new offer letter. The need can be seen directly in the e-catalog and then can contact sales for stock e-checks, although sometimes the goods we are looking for have not been displayed in the e-catalog. Here is a summary of the results of e-procurement benefits according to the procurement staff. 
Table 2. Benefit system of e-procurement according to procurement staff

\begin{tabular}{|c|c|c|}
\hline No. & Aspects & Benefit \\
\hline 1. & Cost saving & $\begin{array}{l}\text { The need can be seen directly in the } \\
\text { e-catalog and then can contact sales for } \\
\text { stock checks, although sometimes the } \\
\text { goods we are looking for have not been } \\
\text { displayed in the e-catalog. There is no } \\
\text { need to go to the goods provider's store } \\
\text { which must require a fare for price surveys, } \\
\text { goods surveys, or trade negotiations. All } \\
\text { can be done through an online application. } \\
\text { If necessary, can be served by telephone } \\
\text { interaction or meeting in person, the } \\
\text { provider will go to the customer's office. }\end{array}$ \\
\hline 2. & Process efficiency & $\begin{array}{l}\text { With e-catalogs, there is no need to wait } \\
\text { for the end of the year to realizethe budget } \\
\text { because it is usually crowded at the end of } \\
\text { theyear, many agencies spend the budget } \\
\text { at the end of the year, so the stock vacancy } \\
\text { can beanticipated early there is no need to } \\
\text { reverse the realization of the budget in the } \\
\text { following year. }\end{array}$ \\
\hline 3. & $\begin{array}{l}\text { Better information } \\
\text { flow between a firm } \\
\text { and suppliers }\end{array}$ & $\begin{array}{l}\text { E-catalog can be a solution for budget } \\
\text { discrepancies, because usually goods/ } \\
\text { service is made in the previous year so } \\
\text { it is sometimes less suitable for example } \\
\text { below the market price because the price } \\
\text { is very volatile, with e-catalog, this can be } \\
\text { anticipated early. }\end{array}$ \\
\hline 4. & $\begin{array}{l}\text { Reduced maverick } \\
\text { spending }\end{array}$ & $\begin{array}{l}\text { Customers can contact the provider directly } \\
\text { without the need for an intermediary and } \\
\text { get a guaranteed warranty card from each } \\
\text { purchase }\end{array}$ \\
\hline
\end{tabular}




\begin{tabular}{|c|c|c|}
\hline No. & Aspects & Benefit \\
\hline 5. & Streamlined Process & $\begin{array}{l}\text { Conventions need to structure HPS, choose } \\
\text { competent providers and be more at risk of } \\
\text { scrutiny by relevant parties. As for e-catalog, } \\
\text { easier and safer, than any area can be sent. } \\
\text { Also, e-catalog can not play money because } \\
\text { it is transparent as well, so all will be } \\
\text { checked until payment through his account } \\
\text { and taxes. Later if it is detected to have } \\
\text { committed such an aberration, both sides } \\
\text { will get a reprimand. So, system e-catalog } \\
\text { already nice and full of supervision }\end{array}$ \\
\hline
\end{tabular}

6. Better Inventory Level

7. Better services to customers

8. Improved speed of services to customers
Checking the stock of goods can be monitored at any time whether the stock of goods is available, deleted, or discontinue making it easier for the user to make purchasing decisions. Related to monitoring and evaluation in case of misses a between the goods ordered and the goods received. That is rare because after the transaction we both from the user/provider make sure first for all budgets, the specification is following the request/RUP Sebelum E-purchase issued. The package that has been issued e-purchase for more than 7 days cannot be canceled for any reason

E-catalogs make it easy for customers to find the goods they want. Many providers offer goods/services. Once browsing, many appear

SPJ (letter of accountability) completeness documents that usually are complicated and take a long time to complete can be resolved immediately because all by the online system with certain Standart Operational Procedures and agreements of the two parties that can be controlled together through the application. 
Table 3. Risks of e-procurement according to procurement staff

\begin{tabular}{|c|c|c|}
\hline No. & $\begin{array}{l}\text { Aspects of } \\
\text { Risks }\end{array}$ & Behavioral Evidence \\
\hline 1. & $\begin{array}{l}\text { Internal } \\
\text { business risks }\end{array}$ & $\begin{array}{l}\text { Many agencies are confused to choose because } \\
\text { many providers offer goods/services. As soon as } \\
\text { you browse, a lot comes up. This is a bit different } \\
\text { from conventional procurement that only meets } \\
\text { the partners we are aiming for. This allows } \\
\text { for business risk on the internal side of the } \\
\text { customer's company because it will be tempting } \\
\text { to change the budget if it finds more attractive } \\
\text { goods, more so if there is no clear budget, } \\
\text { then the purchasing manager representing the } \\
\text { organization will be easily tossed around. }\end{array}$ \\
\hline 2. & $\begin{array}{l}\text { External } \\
\text { business risks }\end{array}$ & $\begin{array}{l}\text { this frequent click error. This miscommunication } \\
\text { only, there are some users as new officials } \\
\text { sometimes have not memorized properly the } \\
\text { goods \& specifications requested differently. } \\
\text { Usually, the provider always in foto the user if } \\
\text { it is correct that will be clicked unit A with this } \\
\text { specification \& ceiling, a quantity so, if already a } \\
\text { new deal we click. If the item is incorrect when } \\
\text { it is clicked can be changed with the E-Purchase } \\
\text { unissued record. In the event of an error that is } \\
\text { not recognized by the perpetrator, it often causes } \\
\text { discomfort on both sides, so it is necessary to } \\
\text { revise the purchase which is quite troublesome } \\
\text { external party of the goods/services provider. }\end{array}$ \\
\hline 3. & $\begin{array}{l}\text { Technology } \\
\text { risks }\end{array}$ & $\begin{array}{l}\text { Sometimes there are technical problems both on } \\
\text { the part of consumers and providers so providers } \\
\text { are considered less responsive and not easy to } \\
\text { communicate because of unstable technology } \\
\text { factors especially if crowded di end of the year } \\
\text { many often occur problems (signal and server } \\
\text { interference), as a result, procurement fails. }\end{array}$ \\
\hline
\end{tabular}




\begin{tabular}{lll}
\hline No. & $\begin{array}{c}\text { Aspects of } \\
\text { Risks }\end{array}$ & \multicolumn{1}{c}{ Behavioral Evidence } \\
\hline 4. & $\begin{array}{l}\text { E-procure } \\
\text { ment ocess } \\
\text { risks }\end{array}$ & $\begin{array}{l}\text { Temporary Estimated Price (HPS) has not } \\
\text { accommodated postage and installation } \\
\text { costs and not all providers of goods/services } \\
\text { are willing to provide HPS friendly when } \\
\text { prospective buyers have to survey prices to } \\
\text { determine HPS. } \\
\text { In this process, there are also sometimes } \\
\text { obstacles, one of which is because the provider's } \\
\text { response is slow so it is difficult to negotiate and } \\
\text { there is a delay until the budget cap finally can } \\
\text { not be realized that year. }\end{array}$ \\
\hline
\end{tabular}

When viewed from the risks and benefits in the table, it turns out that the benefits of implementing e-procurement are more than the risks. The results of this study are in line with the results of previous studies stating that traditional procurement takes care of everything from search, selection, negotiation, request/order, receipt, and review post-purchase which usually takes a long time at a high cost. However, with e-procurement, it feels easier to meet many people in a fast time, so that the implementation of procurement runs lighter (Nawi et al., 2016), very efficient (Ningsih et al., 2015), and without having to come directly to the location and not limited space and time (Linda, 2016).

In addition to those written in the table, data from procurement staff shows there is still a problem that haunts the buyer using e-procurement, namely from the side of the sharia. Halal or not because they still feel like buying a cat in a sack. Whereas if traced, if using the e-procurement procedure appropriately, all transactions are clear and open. So, there should be no doubt in using e-procurement because it does not violate Islamic law as long as the transaction is done honestly, openly, there is clarity of goods, specifications of goods, and prices, and safe from mafsadah (damages), then the transaction is halal (Hediana \& Aly, 2015). Therefore, absolute socialization is done so that all procurement officials, especially in government agencies, get as much information about e-procurement as possible to more steadily following the modern procurement rules set by the government since 2010 . 
The next data comes from the provider. According to the provider, LKPP may be less eager to socialize e-procurement, the office also many do not know the e-catalog. Providers have to introduce themselves whereas many are hesitant especially the account problems that the office has still many are confused. In Malang, 7 out of 8 new agencies implemented e-procurement in 2012, and 1 agency implemented e-procurement in 2011 even though 2010 was already in effect (Wulandari et al., 2014). Anyway, e-catalog is very easy for users as well as providers. WhatsApp alone now can be because all goods can be viewed directly on the web price as well. The rules provided by LKPP according to the provider are good, therefore all for the sake of security and shared comfort either from the provider and the buyer when later held accountable or when there is an examination either from the tax office or the inspectorate. Therefore, standard Operational Procedure (SOP) of internal agencies does not exist, and only follows the governmentmade procurement regulations of goods/services (Presidential Regulation 3 leader regulation of LKPP).

By definition, the risk is a positive or negative effect of the possibility that can occur on an object. All activities in an organization contain risks (Ariani \& Jati, 2016). The biggest risk in e-procurement is internet interference so that requests are not immediately responded to by providers, users do not receive notifications of requests for goods that have been successfully made, stock rushes are exhausted due to internet connection disruptions can result in delayed e-procurement process. This proves that technology plays an important role in conveying information so as to improve transparency, clarity, and transparency (Neupane, 2014).

This research was conducted on procurement officials of goods and services in Indonesia. There is something different about other cultures, Indonesians put forward tepo seliro so sometimes cannot bargain goods when having to negotiate face-to-face. However, with this e-procurement, negotiations are done more easily, there is no psychological burden because there are already rules and not many face-to-face. There's no need to listen to sales offers that take up a lot of work time because they're all already in the e-catalog. E-catalog is one of the e-procurement technologies 
that usually contains the specifications and prices of all products. Suppliers can access directly to the server easily so that they can immediately follow the update information about products from the supplier quickly, sparingly, and accurately (Trkman \& McCormack, 2010).

E-procurement with this e-catalog has advantages over manuals, i.e. no tender/auction required for $\mathrm{K} / \mathrm{L} / \mathrm{D} / \mathrm{I}$ to obtain goods/services; more efficiently saves human resources, time, and cost; transparent price of goods/services and transparent technical specifications (accessible to anyone) because it has a system to check; can choose products as needed (according to quality, brand, function, and service provided); more accountable (more guarantees tranquility in procurement); supports the implementation of government policies/ programs. Thus, services are faster and accountable (Muhaemin, 2019; Innocent \& Kalaskar, 2016).

External risks sometimes occur due to poorly prepared logistical problems (stock exhausted), having to wait (indent) for some time, or it can also be due to risks on the way. Internal risks such as the unpreparedness of customer companies in the face of price changes. There is a disruption of the server system to run e-procurement (Trkman \& McCormack (2010).

Furthermore, researchers identified problems from the seller or provider of goods/services. Good e-catalog criteria for buyers to choose carefully are as follows. If the provider side, it is explained that the provider is strictly affected by LKPP. If there is an overpriced, the provider can be held accountable because all vendors that are already in the e-catalog all data is valid in LKPP so any errors from the provider, can be consulted to LKPP. Also, e-procurement can not play money because it is transparent as well, so all will be checked until payment through his account and taxes. Later if it is detected to have committed such an aberration, both sides will get a reprimand. So the e-catalog system already nice and full of supervision. A good provider that can provide and meet all customer needs, especially for government agencies to provide maximum service.

Related to monitoring and evaluation in case of misses a between the goods ordered and the goods received. That is rare 
because after the transaction we both from the user or provider confirm first for all budgets, specifications are under the request/RUP before-purchase issued. A package that has been issued e-purchase for more than 7 days cannot be canceled for any reason.

For the suitability of goods, providers find it rare to ship the wrong goods. Even if it is wrong once it is only exchanged between one service and another. When called the service can be delivered directly to the warehouse and the day is also immediately exchanged. If for this frequent click error. This is miscommunication only, there are some users as officials new sometimes not memorized properly the goods \& specifications requested by others. We are always informed to the user whether it is correct that will be clicked unit A with this specification and ceiling, a quantity so, if already a new deal we click. If the item is incorrect when it has been clicked can be changed with the note that has not been issued e-purchase. If the re-purchase has been issued, there are 2 possibilities, can be canceled or can not even be canceled. It's the policy of the LKPP. That is rare because after the transaction we both from the user or provider confirm first for all budgets, specifications are following the request/AGMS before e-purchase issued. A package that has been issued e-purchase for more than 7 days cannot be canceled for any reason.

E-procurement is superior in terms of efficiency, transparency, and providing procurement opportunities to the public. Some of the benefits of implementing e-procurement include increased efficiency, the achievement of supply chain management, increased level of service to customers, reduction of process time, reduction of operational tasks, and reduction of transaction costs. But in its application there are also constraints such as the organization's reluctance to implement e-procurement, arguing that users are already comfortable with manual procurement practices, lack of adequate resources, too expensive to implement, user perception that e-procurement does not provide any benefits at all, data security issues, and inadequate knowledge in implementing e-procurement.

To address this, organizations need to commit to implementing e-procurement, among others by creating accountable purchasing 
processes and regulating structural changes, providing human resources that manage information systems and have expertise on the internet, downsizing the approval process and workflow systems, as well as top management engagement and commitments (Ariani \& Jati, 2016). Offers with e-catalog usually do not use the offer letter or it can be said that the offer letter is given by request that is when the agency asks for a new offer letter. This needs to be better prepared for smoother transactions.

Related to sharia doubts, e-procurement is not in doubt because it fulfills the object of the contract required in the concept of muamalah. The object of a contract or expensive al-'Aqd is something that becomes an object of the agreement and has implications for the consequences of the law. Objects such as computer machines and printers, or anything do not have benefits. The conditions that must be met in Mahall al-'Aqd are that the object of the agreement must exist when the contract is done, the object of the agreement does not violate sharia must be clear and recognized, and can be surrendered (Sitepu, 2017). E-procurement even though the process passes through electronics, all open, clear, the goods do not violate sharia, and are acceptable. Muamalah with this technology has also begun to be widely accepted in the community, for example, transportation online and go food that has been judged to meet Sharia rules (Yunus et al., 2018).

\section{Conclusion}

Based on the above description, it can be concluded that e-procurement is a new model of muamalah applied in the procurement of goods/services in several countries, in Indonesia was enacted starting in 2010. Although it has been in effect for a decade, the implementation is not yet maximal. There are still doubts because it is not familiar with this modern muamalah model and still incomplete information about e-procurement obtained by procurement officers or officials in agencies, especially government agencies. The results of the research show that such doubts do not need to exist because in terms of religion, e-procurement is proven not to violate Islamic sharia because transactions are open, clear, and there is no coercion between the buyer and the seller (provider). Even from benefit (benefit) more than risk (mafsadat). 
The advice from the results of this research is as follows. Standard Operational Procedures for providers, the maximum time for purchase package response, and providers multiply branch offices to minimize postage charges to buyers. Complete socialization of consultant assistance e-procurement is necessary so that procurement officials understand comprehensively about e-procurement and can carry it out with confidence including socialization about e-procurement from an Islamic economic perspective (muamalah) so that officials do not hesitate to carry out their duties using e-procurement.

Alsa, the rules, operational standards of procedures, supervision, and evaluation still have to be carried out to control the purpose of the enactment of e-procurement in all government agencies in Indonesia given that it has been found that if there are pressures of discipline, then procurement officials will be more careful to carry out their duties, whereas if there are opportunities to misappropriation of procurement, then procurement officers will be easier to commit fraud as well. Because clear rules are needed along with consequences that must be enforced in the event of procurement misappropriation because it will again harm the state. 


\section{References}

Achterstraat, (2011). "Compliance Review Report-Procurement Reform of E-procurement and E-Tendering". The Legislative Council Parliament House, Sydney.

Ariani, A.F. \& Jati, R.K. (2016). "Analisis Risiko pada Proses Pengadaan Melalui E-Procurement di Pusat Penelitian X". Paper in $11^{\text {th }}$ Annual Meeting on Testing and Quality Lembaga Ilmu Pengetahuan Indonesia.

Artantri, L.P.R.M., Handajani, L. \& Pituringsih, E. 2016. "Peran E-Procurement Terhadap Pencegahan Fraud pada Pengadaan Barang/Jasa Pemerintah Daerah di Pulau Lombok". NeO Bis, 10(1), 16-32.

Apriyanto, E. (2019). "Kerjasama dengan Sistem E-Procurement Perspektif Hukum Ekonomi Syariah (Studi Kasus Kementerian Agama Kabupaten Cilacap)". Thesis, IAIN Purwokerto.

Fernandes, T. dan Vieira, V. (2015). "Public E-Procurement Impacts in Small- And Medium-Enterprises". International Journal of Procurement Management, 8(5), 587-607.

Hanna, N.K. 2010. "Transforming Government and Building the Information Society: Challenges and Opportunities for the Developing world", Springer Verlag.

Khanapuri, V.B., Nayak, S., Soni, P., Sharma, S., \& Soni, M. (2011). "Framework to Overcome Challenges of Implementation of E-Procurement in Indian Context". Paper presented to International Conference on Technology and Business Management, Dubai, March 28-30, 2011.

Hardi, A.T. (2017). "E-Katalog Persempit Kesempatan Korupsi". Mediaindonesia.com Selasa, 25 Juli 2017, 19.00 WIB.

Hediana, R. \& Aly, A.D. (2015). "Transaksi Jual Beli Online Perspektif Ekonomi Islam. Jurnal Penelitian Hukum ekonomi Syariah", $3(2), 41-53$.

Innocent, R. \& Kalaskar, P.B. (2016). "The Adoption of e-Procurement and ints impact on the Procurement Performnace of Selected Telecommunication Companies in Rwanda". European Journal of Business and Management, 8(15), 125-133.

Linda, D. (2016). "Merancang e-katalog Berbasis Website Sebagai Media Informasi pada Badan Perpustakaan Arsip dan Dokumentasi Daerah (BPAD) Lampung". Jurnal Sistem Informasi dan Telematika (Telekomunikasi, Multimedia, dan 
Informasi) Vol 6, No.2: 1-11.

Muhaemin, E.A. (2019). "Kebijakan dalam E-Purchasing dan E-Katalog”. Direktorat Pengembangan Sistem Katalog-LKPP.

Nawi, M.N.M., Roslan, S., Salleh, N.A., \& Zulhumadi, F. (2016). "The Benefits and Challenges of E-Procurement Implementation: A Case Study of Malaysian Company". International Journal of Economics and Financial Issues, 6(7), 329-332.

Neupane, A., Soar, J., Vaidya, K., \& Yong, J. (2012). "Role of Public e-Procurement Technology to Reduce Corruption in Government Procurement". International Public Procurement Conference, August 17-19. 304-334.

Neupane, A., Soar, J., Vaidya, K., \& Yong, J. (2014). 'Willingness to Adopt e-procurement to reduce corruption: Results of the PLS Path Modeling". Transforming Government: People, Process and Policy, 8(4), 500-520.

Ningsih, A., Fudholi, A., \& Sumarni. (2015). 'Hubungan Penerapan Elektronik Katalog Terhadap Efisiensi Pengadaan dan Ketersediaan Obat". Jurnal Manajemen dan Pelayanan Farmasi, 5(4), 241-248.

Nurlukman, Adie Dwiyanto. (2017). "E-procurement: Inovasi Penyelenggaraan Pemerintahan dalam Pengadaan Barang dan Jasa Berbasis e-Government di Indonesia”. Journal of Government and Civil Society, 1(1), 81-93.

Nurmandi, A. (2013). "What Is The Status of Indonesia's E-Procurement?" Jurnal Studi Pemerintahan, 4(2), 1-38.

Nurmandi, A. \& Kim, S. (2015). "Making E-Procurement Work in a Decentralized Procurement System. A Comparison of Three Indonesian Cities". International Journal of Public Sector Management, 28(3), 198-220.

Purwanto, E., Mulyadi, \& Anwar, C. (2017). "Kajian Konsep Diamond Fraud Theory dalam Menunjang Efektivitas Pengadaan Barang/ Jasa di Pemerintah Kota Bogor". Jurnal Manajemen Indonesia, 17(3), 149-162.

Saputra, W. A., Puspandari, D.A., \& Kurniawan, M.F. (2019). "Evaluasi Pengadaan Obat dengan E-Purchasing Melalui E-Katalog di Rumah Sakit Jiwa Grasia Daerah Istimewa Yogyakarta Tahun 2017-2018". Jurnal Kebijakan Kesehatan Indonesia: JKKI, 8(3), 113-120. 
Shukla, A., Khan, M.A., \& Shah, M. (2016). "Literature Review of Adoption of E-Procurement Practices by Construction Industries". Journal of Management \& Research, 10(2/4), 1-25.

Sitepu, Novi Indriyani. (2017). "Tinjauan Muamalah Pengetahuan Masyarakat Banda Aceh Mengenai Akad Tabarru' dan Tijarah". Islamic Business Law Review: Jurnal Hukum Ekonomi Syariah, 1(1), 89-99.

Sugiyono. 2010. "Metode Penelitian Kuantitatif, Kualitatif, dan $R \notin D ”$. Bandung: Alfabeta.

Swadesi, Utari. (2017). "Efektivitas Pengadaan Barang dan Jasa Secara Elektronik (e-procurement) pada LPSE Kota Pekanbaru". Journal of Management, 4(2), 1-13.

Trkman, P. \& McCormack, K. (2010). "Estimating the Benefits and Risks of Implementing E-Procurement". Transactions on Engineering Management, 57(2), 338-349.

Tim Readaksi KPK. (2018). "Jejak Pemberantasan Korupsi” diakses tanggal 18 April 2020 dari https://acch.kpk.go.id/id/statistik/ tindak-pidana-korupsi/tpk-berdasarkan-jenis-perkara

Udoyono, K. (2012). "E-Procurement dalam Pengadaan Barang dan Jasa untuk Mewujudkan Akuntabilitas di Kota Yogyakarta". Jurnal Studi Pemerintahan, 5(1), 135-171.

Vaidya, K., Sajeev, A. S. M., \& Callender, G. (2006). "Critical Factors that Influence E-Procurement Implementation Succses in the Public Sector". Journal of Public Procurement, 6(1 \& 3), 70-99.

Wulandari, L. I., EL Unas, S., \& Hasyim, M. H. (2014). "Kajian Penerapan E-Procurement untuk Mengurangi Penyimpangan pada Pengadaan Pekerjaan Konstruksi di Kota Malang". Jurnal Rekayasa Publik, 8(1), 7-16

Yunus, M., Hamdani, F.F.R.S., \& Shofia, G.K. (2018). "Tinjauan Fikih Muamalah terhadap Akad Jual Beli dalam Transaksi Online pada Aplikasi Go-Food". Amwaluna: Jumal Ekonomi dan Keuangan Syariah, 2(1), 134-146. 